\title{
Long-Lasting GABA-Mediated Depolarization Evoked by High- Frequency Stimulation in Pyramidal Neurons of Rat Hippocampal Slice Is Attributable to a Network-Driven, Bicarbonate-Dependent $\mathrm{K}^{+}$Transient
}

\author{
Kai Kaila, Karri Lamsa, Sergei Smirnov, Tomi Taira, and Juha Voipio \\ Department of Biosciences, Division of Animal Physiology, University of Helsinki, FIN-00014 Helsinki, Finland
}

Biphasic $\mathrm{GABA}_{\mathrm{A}}$-mediated postsynaptic responses can be readily evoked in CA1 pyramidal neurons of rat hippocampal slices by high-frequency stimulus (HFS) trains in the presence of ionotropic glutamate receptor antagonists. In the present experiments with sharp microelectrodes, whole-cell techniques, and $\mathrm{K}^{+}$-selective microelectrodes, an HFS train (40 pulses at $100 \mathrm{~Hz}$ ) applied in stratum radiatum close to the recording site evoked a brief hyperpolarizing IPSP (hIPSP), which turned into a prolonged (2-3 sec) depolarization (GABAmediated depolarizing postsynaptic potential; GDPSP). The I-V relationships of the postsynaptic currents (hIPSC and GDPSC) had distinct characteristics: the hIPSC and the early GDPSC showed outward rectification, whereas the late GDPSC was reduced with positive voltage steps to zero or beyond (inward rectification), but often no clear reversal was seen. That two distinct currents contribute to the generation of the GDPSP was also evident from the finding that a second HFS train at peak or late GDPSP induced a prompt $\mathrm{GABA}_{\mathrm{A}}$-mediated hyperpolariza- tion. The GDPSP/C was dependent on the availability of bicarbonate, but not on interstitial or intrapyramidal carbonic anhydrase activity.

The HFS train evoked a rapid $\mathrm{GABA}_{\mathrm{A}}$-mediated bicarbonatedependent increase in the extracellular $\mathrm{K}^{+}$concentration $\left(\left[\mathrm{K}^{+}\right]_{\mathrm{o}}\right)$, and the GDPSP followed the $\mathrm{K}^{+}$transient in a subNernstian manner. The spatial and pharmacological characteristics of the $\left[\mathrm{K}^{+}\right]_{\mathrm{o}}$ shift indicated that it is generated by a local network of GABAergic interneurons. The brief ascending phase of the GDPSP is linked to a $\mathrm{K}^{+}$-dependent accumulation of intracellular $\mathrm{Cl}^{-}$. Thereafter, a nonsynaptic mechanism, a direct depolarizing effect of the $\left[\mathrm{K}^{+}\right]_{0}$ shift, is responsible for the most conspicuous characteristics of the GDPSP: its large amplitude and prolonged duration.

Key words: $G A B A_{A}$ receptor; postsynaptic depolarization; bicarbonate; potassium; hippocampal pyramidal neuron; inhibitory network; glial depolarization
Fast inhibitory $\mathrm{GABA}_{\mathrm{A}}$ receptor-mediated postsynaptic potentials (fIPSPs) evoked by single stimuli in hippocampal pyramidal neurons are strongly hyperpolarizing, with a reversal potential 15-20 mV more negative than the resting membrane potential (for references, see Nicoll et al., 1990). This is consistent with the presence of a powerful $\mathrm{Cl}^{-}$-extruding mechanism (most likely a $\mathrm{K}^{+}-\mathrm{Cl}^{-}$cotransporter) in pyramidal neurons (Thompson and Gähwiler, 1989a; Jensen et al., 1993) (for review, see Kaila, 1994; Payne et al., 1996). However, a biphasic postsynaptic response that also is mediated by GABA and that consists of an initial hyperpolarizing IPSP (hIPSP), followed by a slow depolarization, can be readily evoked in hippocampal pyramidal neurons by high-frequency stimulation of inhibitory interneurons in the presence of ionotropic glutamate receptor antagonists (Davies and Collingridge, 1993; Grover et al., 1993; Staley et al., 1995). Because the amplitude of the slow depolarization is often sufficient to elicit spike firing, which by definition means that this response is excitatory rather than inhibitory, we prefer calling it a GABAmediated depolarizing postsynaptic potential (GDPSP) rather than a "depolarizing IPSP" (cf. Grover et al., 1993).

\footnotetext{
Received May 12, 1997; revised July 21, 1997; accepted Aug. 5, 1997.

This study was supported by grants from the Academy of Finland and from the Sigrid Jusélius Foundation.

Correspondence should be addressed to Dr. K. Kaila, Department of Biosciences, Division of Animal Physiology, University of Helsinki, P.O. Box 17, FIN-00014 Helsinki, Finland.

Copyright (C) 1997 Society for Neuroscience $\quad 0270-6474 / 97 / 177662-11 \$ 05.00 / 0$
}

The ionic mechanism of generation of the GDPSP has been a long-lasting and well recognized enigma (Nicoll et al., 1990; Kaila, 1994; Lambert and Grover, 1995). It has been suggested recently (Staley et al., 1995) that this $\mathrm{GABA}_{\mathrm{A}}$ receptor-mediated excitatory response is the result of an asymmetric, activitydependent collapse of the opposing electrochemical gradients of the two anions (chloride and bicarbonate) that are permeant across $\mathrm{GABA}_{\mathrm{A}}$ receptors (Bormann et al., 1987; Kaila and Voipio, 1987). According to the scheme of Staley et al. (1995), the bicarbonate current generated during intense activation of $\mathrm{GABA}_{\mathrm{A}}$ receptors in a pyramidal neuron leads to a large depolarization-driven gain in postsynaptic $\mathrm{Cl}^{-}$. There is only a modest net loss of postsynaptic $\mathrm{HCO}_{3}^{-}$, because the latter is thought to be replenished effectively by the action of both an interstitial (cf. Kaila et al., 1992) and intrapyramidal (cf. Pasternack et al., 1993) carbonic anhydrase. This kind of a mechanism has its precedent in work on crayfish muscle fibers, in which direct measurements of the two anions showed that tonic activation of $\mathrm{GABA}_{\mathrm{A}}$ receptor channels can lead to a $\mathrm{HCO}_{3}^{-}$-dependent depolarization and to a consequent channel-mediated accumulation of intracellular $\mathrm{Cl}^{-}$(Kaila and Voipio, 1987; Kaila et al., 1989).

The present study supports a key role for $\mathrm{HCO}_{3}^{-}$ions in GABAergic depolarization of CA1 pyramidal neurons in rat hippocampal slices. However, our observations indicate that a postsynaptic bicarbonate current in the pyramidal neuron cannot account for the two characteristic properties of the GDPSP, its 
extremely positive reversal potential and its prolonged duration. A hypothesis consistent with presently available data (see also Lamsa and Kaila, 1997) is based on a mechanism with a dual role for an activity-induced extracellular $\mathrm{K}^{+}\left(\left[\mathrm{K}^{+}\right]_{\mathrm{o}}\right)$ transient that is generated in an $\mathrm{HCO}_{3}^{-}$-dependent manner by a local inhibitory network. The initial fast positive shift in the reversal potential of the relatively short-lived $\mathrm{GABA}_{\mathrm{A}}$ receptor-mediated current evoked by a high-frequency stimulus (HFS) train is linked to a postsynaptic accumulation of $\mathrm{Cl}^{-}$in response to the $\left[\mathrm{K}^{+}\right]_{\mathrm{o}}$ transient. Thereafter, a direct depolarizing action of the $\left[\mathrm{K}^{+}\right]_{\mathrm{o}}$ shift governs the behavior of the GDPSP.

Some preliminary findings have been published in abstract form (Kaila et al., 1995; Voipio et al., 1996).

\section{MATERIALS AND METHODS}

Slice preparation and maintenance. Hippocampal slices $(400 \mu \mathrm{m})$ were prepared as described elsewhere (Voipio et al., 1995) from brains of 30to 45 -d-old male Wistar rats $(100-120 \mathrm{gm})$. The standard physiological solution that was used contained (in $\mathrm{mM}$ ): $\mathrm{NaCl} \mathrm{124,} \mathrm{KCl} 3.0, \mathrm{CaCl}_{2} 2.0$, $\mathrm{NaHCO}_{3} 25, \mathrm{NaH}_{2} \mathrm{PO}_{4} 1.1, \mathrm{MgSO}_{4} 2.0$, and D-glucose 10. It was gassed continuously with $95 \% \mathrm{O}_{2} / 5 \% \mathrm{CO}_{2}, \mathrm{pH} 7.4$, at the experimental temperature of $32^{\circ} \mathrm{C}$. The slices were allowed to recover for $\sim 1 \mathrm{hr}$ at room temperature before being placed into the interface-type recording chamber. In some experiments $\mathrm{NaHCO}_{3}$ was replaced by $20 \mathrm{~mm}$ HEPES, $\mathrm{pH}$ 7.4 with $\mathrm{NaOH}$, and the solution was equilibrated with $100 \% \mathrm{O}_{2}$.

Stimulation and recording. Synaptic responses in CA1 pyramidal neurons were evoked by stimuli $(20 \mathrm{~V}$ for $50-100 \mu \mathrm{sec})$ delivered with a bipolar electrode placed in stratum radiatum at a distance of $\sim 0.5 \mathrm{~mm}$ from the site of recording. The standard high-frequency train of stimuli consisted of 40 pulses delivered at $100 \mathrm{~Hz}$; occasionally, 100 pulses were applied at $200 \mathrm{~Hz}$. Single stimuli usually were given at a rate of $<0.05 \mathrm{~Hz}$ and in some experiments at $0.5 \mathrm{~Hz}$ (compare Fig. 7).

Intracellular recordings from CA1 pyramidal neurons were obtained by using sharp microelectrodes or patch pipettes. The sharp microelectrodes were filled with a solution containing $1.5 \mathrm{M} \mathrm{K}$-acetate, $1.5 \mathrm{M}$ $\mathrm{K}$-methane sulfonate, and $5 \mathrm{~mm} \mathrm{KCl}, \mathrm{pH}$ 6.8-7.0. They had a resistance of $80-120 \mathrm{M} \Omega$ and were used for recording in bridge mode. Only cells with a stable membrane potential of -60 to $-75 \mathrm{mV}$ and an input impedance of 20-80 $\mathrm{M} \Omega$ were used for measurements.

Whole-cell recordings were obtained by using the method of Blanton et al. (1989). An Axoclamp 2A amplifier (Axon Instruments, Foster City, CA) was used either in continuous voltage-clamp mode or in bridge mode. The whole-cell patch pipettes had a resistance of 6-9 $\mathrm{M} \Omega$ when filled with a solution containing (in $\mathrm{mM}$ ): K-gluconate $120, \mathrm{MgCl}_{2} 2.0$, Mg-ATP 5.0, HEPES 10, K-BAPTA or K-EGTA 2, and D-glucose 20, pH 7.1 with $\mathrm{NaOH}$. The input impedance during the temporary "on-cell" configuration exceeded $1 \mathrm{G} \Omega$, and, immediately after rupturing of the membrane, the membrane potential was usually -45 to $-50 \mathrm{mV}$ and cell impedance was $80-100 \mathrm{M} \Omega$. Within 5 min these parameters stabilized at a level of -50 to $-70 \mathrm{mV}$ and $100-500 \mathrm{M} \Omega$ (typically $150-200 \mathrm{M} \Omega$ ), respectively.

$\mathrm{K}^{+}$-selective microelectrodes with a short column of the ion sensor (Fluka 60938, Buchs, Switzerland) were made from double-barreled borosilicate glass pipettes, using techniques described before (Voipio et al., 1995). The reference barrel was filled with $150 \mathrm{~mm} \mathrm{NaCl}$. The resistance of the two barrels was $10-20 \mathrm{G} \Omega$ and $10-20 \mathrm{M} \Omega$. The electrode responses were calibrated in terms of free concentration, and they had a slope of $56-59 \mathrm{mV}$ for a 10 -fold change in $\left[\mathrm{K}^{+}\right]$.

Drugs. All experiments (except for those related to Fig. $8 A$ ) were made in the presence of ionotropic glutamate receptor antagonists, $10 \mu \mathrm{M}$ 6-nitro-7-sulfamoylbenzo(f)-quinoxaline-2,3-dione (NBQX), $40 \mu \mathrm{M} \mathrm{D-2-}$ amino-5-phosphonopentoate (AP5), and $50 \mu \mathrm{M}$ ketamine. Picrotoxin was applied in some experiments at a concentration of $100 \mu \mathrm{M}$. In most experiments $\mathrm{GABA}_{\mathrm{B}}$ receptors were blocked with bath-applied $200 \mu \mathrm{M}$ CGP 35348 (kindly donated by Dr. M. Pozza, Ciba-Geigy, Basel, Switzerland), by $200 \mu \mathrm{M}$ 2-hydroxy-saclofen, and/or by the addition of 50-100 $\mu \mathrm{M}$ QX-314 into the whole-cell electrode filling solution. A few experiments were performed with bath-applied atropine $(5 \mu \mathrm{M})$ or eserine (5-10 $\mu \mathrm{M})$. Benzolamide (BA), a poorly permeant inhibitor of carbonic anhydrase, either was applied in the bath $(10 \mu \mathrm{M})$ or was perfused intracellularly $(100 \mu \mathrm{M})$, using the whole-cell recording electrode. Ethoxyzolamide (EZA), a membrane-permeant carbonic anhydrase in-
A sharp microelectrode
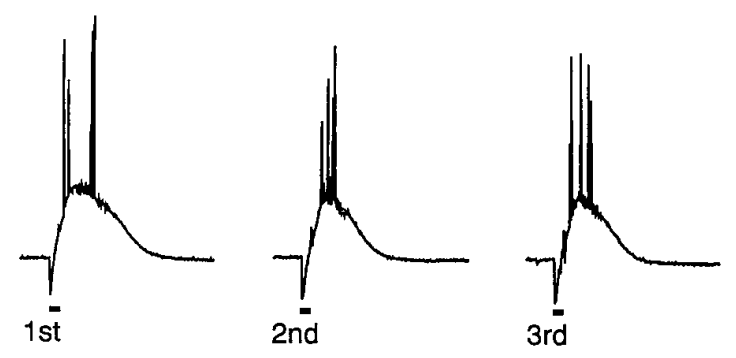

B

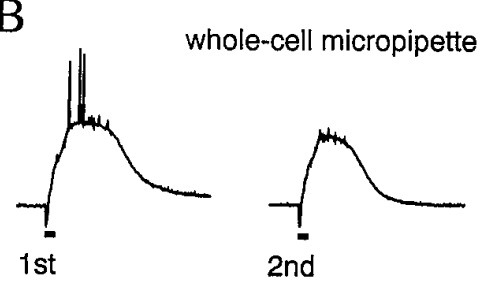

Figure 1. Postsynaptic voltage responses evoked by the standard HFS train $(40$ pulses at $100 \mathrm{~Hz})$ in the presence of ionotropic glutamate receptors. The first three responses from two cells recorded with a sharp microelectrode or a whole-cell micropipette are shown. Note the somewhat more pronounced depolarization evoked by the first HFS train. In this and subsequent figures, the timing of the HFS train (40 pulses at 100 $\mathrm{Hz}$ ) is indicated by a horizontal bar.

hibitor, was applied at $50 \mu \mathrm{M}$ in the bathing solution. BA was obtained as a gift from Lederle Laboratories (American Cyanamid, Washington, DC), and EZA was a gift by Professor Gerolf Gros (University of Hannover, Hannover, Germany). NBQX and AP5 were obtained from Tocris Cookson (Bristol, UK). All other chemicals were obtained from Sigma (St. Louis, MO).

Below, data are given as mean \pm SEM, if not stated otherwise.

\section{RESULTS}

\section{Characterization of postsynaptic responses}

Postsynaptic potentials

In agreement with previous results obtained in the presence of ionotropic glutamate antagonists (Grover et al., 1993; Staley et al., 1995), the standard HFS train (40 pulses at $100 \mathrm{~Hz}$ ) applied to the s. radiatum close to the intracellular recording site evoked a fused sequence of initially hyperpolarizing fast IPSPs (fI PSPs). As seen in recordings obtained with both sharp microelectrodes and whole-cell pipettes (Fig. $1 A, B$ ), the hyperpolarizing phase of the fused response (to be called the hIPSP) reached its peak amplitude of approximately $-10 \mathrm{mV}$ usually within $\sim 30-50 \mathrm{msec}$ and thereafter turned promptly (within 200-300 msec; see Table 1) into a prolonged depolarization (the GDPSP) that often had an amplitude sufficient to trigger a burst of action potentials. Qualitatively similar responses were seen when 100 pulses were given at $200 \mathrm{~Hz}$, which resulted in a slightly larger depolarizing response and somewhat more intense spiking (data not shown). All of the statistics given below are from responses to the standard 40 pulse $/ 100 \mathrm{~Hz}$ train.

A prominent feature of the GDPSP evoked in the present manner is that its duration is much longer than the period of stimulation. For reasons not clear at present, we found that the first GDPSP evoked in any given slice consistently had an amplitude and a duration that exceeded by $15-25 \%$ those elicited later. After the first response, the GDPSP stabilized at a more constant level when the trains of stimuli were applied at intervals of 3-5 
Table 1. Characteristics of the postsynaptic responses

\begin{tabular}{|c|c|c|c|c|c|c|}
\hline & \multicolumn{2}{|l|}{ hIPSP } & \multirow{2}{*}{$\begin{array}{l}\text { Time to reversal } \\
\text { of polarity } \\
(\mathrm{msec})\end{array}$} & \multicolumn{3}{|l|}{ GDPSP } \\
\hline & $\begin{array}{l}\text { Amplitude } \\
(\mathrm{mV})\end{array}$ & $\begin{array}{l}\text { Time }^{a} \text { to peak } \\
(\mathrm{msec})\end{array}$ & & $\begin{array}{l}\text { Amplitude } \\
(\mathrm{mV})\end{array}$ & $\begin{array}{l}\text { Time to peak } \\
(\mathrm{sec})\end{array}$ & $\begin{array}{l}\text { Half-decay } \\
\text { (sec) }\end{array}$ \\
\hline Sharp microelectrode & $\begin{array}{l}10.8 \pm 0.6 \\
(n=53)\end{array}$ & $\begin{array}{l}36 \pm 3 \\
(n=53)\end{array}$ & $\begin{array}{l}232 \pm 12 \\
(n=53)\end{array}$ & $\begin{array}{l}20.2 \pm 0.6 \\
(n=46)\end{array}$ & $\begin{array}{l}1.29 \pm 0.05 \\
(n=46)\end{array}$ & $\begin{array}{l}2.85 \pm 0.10 \\
(n=46)\end{array}$ \\
\hline Whole-cell micropipette & $\begin{array}{l}9.9 \pm 0.5 \\
(n=55)\end{array}$ & $\begin{array}{l}44 \pm 3 \\
(n=55)\end{array}$ & $\begin{array}{l}286 \pm 18 \\
(n=55)\end{array}$ & $\begin{array}{l}17.5 \pm 0.5 \\
(n=47)\end{array}$ & $\begin{array}{l}1.50 \pm 0.05 \\
(n=47)\end{array}$ & $\begin{array}{l}2.95 \pm 0.09 \\
(n=47)\end{array}$ \\
\hline
\end{tabular}

\begin{tabular}{|c|c|c|c|c|}
\hline & \multirow{2}{*}{ 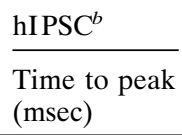 } & \multirow{2}{*}{$\begin{array}{l}\text { Time to reversal } \\
\text { of current } \\
(\mathrm{msec})\end{array}$} & \multicolumn{2}{|l|}{$\mathrm{GDPSC}^{b}$} \\
\hline & & & $\begin{array}{l}\text { Time to peak } \\
(\mathrm{sec})\end{array}$ & $\begin{array}{l}\text { Half-decay } \\
\text { (sec) }\end{array}$ \\
\hline Whole-cell micropipette & $\begin{array}{l}51 \pm 3 \\
(n=37)\end{array}$ & $\begin{array}{l}277 \pm 20 \\
(n=37)\end{array}$ & $\begin{array}{l}1.11 \pm 0.04 \\
(n=31)\end{array}$ & $\begin{array}{l}2.29 \pm 0.08 \\
(n=31)\end{array}$ \\
\hline
\end{tabular}

${ }^{a}$ All values for time courses refer to onset of HFS train.

${ }^{b}$ Data obtained from measurements at resting membrane potential.

min. Hence, the first response was omitted from all quantitative measurements and illustrations except for Figure 1, $A$ and $B$. However, during lengthy experiments some "run-down" of the GDPSP often was evident, which usually involved a decrease in its duration rather than in the amplitude.

We found no clear differences in the amplitude of GDPSPs recorded with sharp microelectrodes and whole-cell pipettes, but the time course of the response seemed to be somewhat slower in whole-cell recordings (see Table 1). The GDPSP reached its peak amplitude of $\sim 15-20 \mathrm{mV}$ with a delay of $1.0-1.5 \mathrm{sec}$ as measured from the onset of the stimulus train, and the decay to $50 \%$ of maximum amplitude took place at $\sim 3 \mathrm{sec}$. Both the hIPSP and the GDPSP were abolished by the $\mathrm{GABA}_{\mathrm{A}}$ receptor antagonist picrotoxin, with the GDPSP showing a higher sensitivity to this blocker (data not shown; see Grover et al., 1993; Taira et al., 1997).

Application of the $\mathrm{GABA}_{\mathrm{B}}$ antagonists CGP $35348(200 \mu \mathrm{M})$ or 2-hydroxy-saclofen $(200 \mu \mathrm{M})$ did not have a major influence on the biphasic postsynaptic response, and only a slight enhancement of both the duration and amplitude of the GDPSP usually was seen (cf. Grover et al., 1993). Nevertheless, all quantitative data and specimen recordings shown in the illustrations were obtained in the presence of bath-applied $\mathrm{GABA}_{\mathrm{B}}$ antagonists (see Materials and Methods). In addition, the whole-cell pipette solution usually contained QX-314 $(50-100 \mu \mathrm{M})$, known to block both postsynaptic spiking and $\mathrm{GABA}_{\mathrm{B}}$ receptors (Nathan et al., 1990).

Because, under certain experimental conditions, synaptic responses evoked in CA1 pyramidal neurons can include a prominent component mediated by muscarinic receptors (Cole and Nicoll, 1984), we examined the effects of bath-applied atropine (5 $\mu \mathrm{M})$ and eserine (5-10 $\mu \mathrm{M})$. However, neither drug had any discernible effect on the GDPSP.

\section{Postsynaptic currents}

In whole-cell voltage-clamp experiments, the current (hIPSC) that corresponded to the hIPSP was outwardly directed and showed rapid fading (Fig. $2 A$ ). In cells clamped at their resting membrane potential, a reversal of the polarity of the current took place at $\sim 290 \mathrm{msec}$ after the onset of stimulation (see Table 1). The peak of the hIPSC had a reversal potential of $-74.2 \pm 1.4$
$\mathrm{mV}(n=19)$. The peak amplitude of the hIPSP/C evidently was affected by the fast anionic redistribution that takes place during repetitive stimulation (see below), because the reversal potential of the hIPSC was less negative than that of single pulse-evoked fIPSCs, which reversed at $-79.5 \pm 1.2 \mathrm{mV}(n=49)$.

The hIPSC was followed by a current (to be called GDPSC) that was inwardly directed at resting membrane potential. In comparison to GDPSPs recorded with whole-cell pipettes, the GDPSC had a significantly faster time course, with an average time to peak (from the onset of the HFS train) of $1.11 \mathrm{sec}$ and a time to $50 \%$ decay of $2.29 \mathrm{sec}$ (see Table 1 ).

Preliminary examinations of the $I-V$ relationships of the GDPSC revealed initially a surprising amount of variation within a single set of recordings, which turned out to be attributable to slight changes in the time point selected for the analysis. Hence, we made $I-V$ plots at intervals of $100-200 \mathrm{msec}$, which revealed a consistent time dependence of the $I-V$ characteristics.

As shown in Figure $2 B$, the $I-V$ curves of the hIPSC and the early (high-conductance) phase of the GDPSC showed outward rectification at positive holding potentials; significantly, there was a prompt shift of the consecutive $I-V$ curves taken at $200 \mathrm{msec}$ intervals, which yielded more positive values for the GDPSC reversal potential as a function of time (Fig. $2 C$ ).

The $I-V$ behavior of the late (low-conductance) phase of the GDPSC was intriguing because not only was the current progressively reduced with positive voltage steps, but very often no clear reversal was seen even at voltages close to zero or beyond (sometimes up to $+15 \mathrm{mV}$ ). Inward rectification of this kind is opposite to what is expected from a $\mathrm{GABA}_{\mathrm{A}}$ receptor-mediated current (for references, see Kaila, 1994). Hence, it was of much interest that a similar type of "asymptotic" behavior at positive voltages was also typical for $I-V$ curves related to glial depolarizations evoked by stimulation-induced $\left[\mathrm{K}^{+}\right]_{\mathrm{o}}$ transients that took place at the site of recording under the present experimental conditions (see below and Fig. 11).

Because of the time-dependent properties of the GDPSC, it was difficult to select a single unique parameter for its quantitative characterization. A parameter with some physiological relevance is, perhaps, the reversal potential obtained at the instant at which 


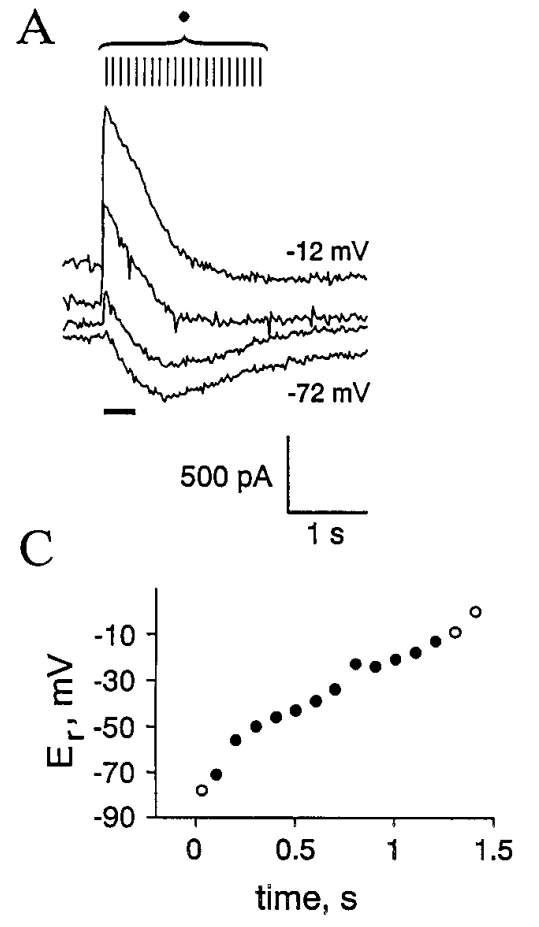

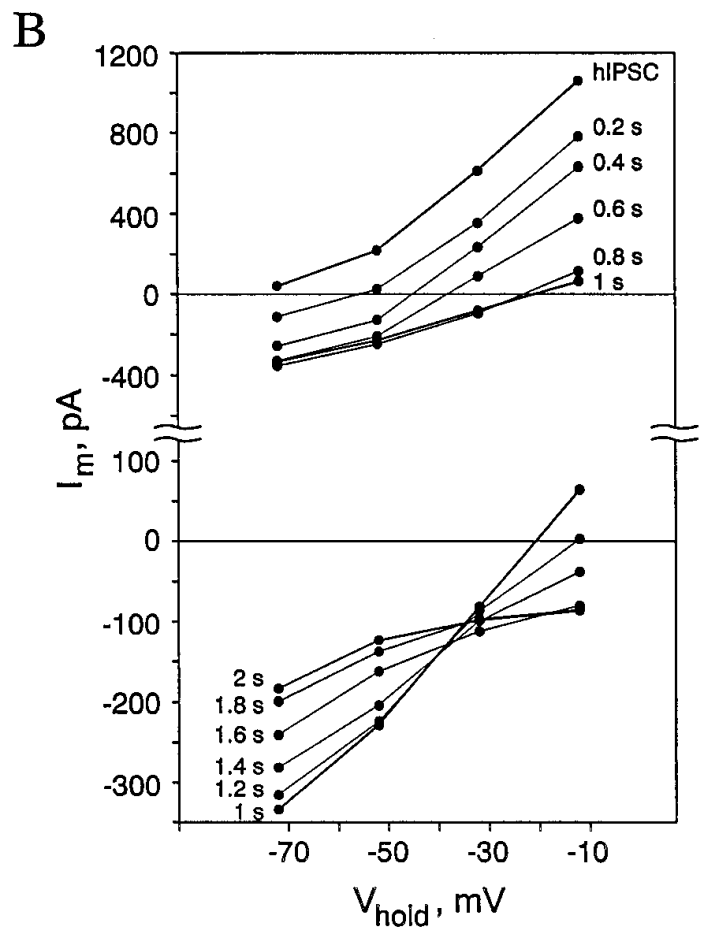

Figure 2. Properties of postsynaptic current responses evoked by the standard HFS train under voltage-clamp conditions. $A$, Specimen recordings of currents. Vertical bars indicate the timing of $I-V$ samples. $B$, Consecutive $I-V$ curves taken at $0.2 \mathrm{sec}$ intervals from the family of recordings in $A$, with the onset of the HFS train assigned time 0 . To facilitate visual inspection, the curves related to $0-1.0$ sec (top panel) and 1.0-2.0 sec (bottom panel) are given separately, with a different scale for current amplitudes. $C$, Change in the reversal potential of the hIPSC/GDPSC as a function of time sampled at $0.1 \mathrm{sec}$ intervals (open symbols represent extrapolated values; see $B$ ). Note that from 1.5 to $2.0 \mathrm{sec}$, the $I-V$ slope is too shallow to yield a meaningful extrapolation. the GDPSC attains its maximum value when recorded at the resting potential. This gave a mean of $-28 \mathrm{mV}$ (range from -22 to $-43 \mathrm{mV} ; n=18$ ) in the present experiments.

\section{Relationships between postsynaptic conductance and voltage responses}

In line with the voltage-clamp data, simultaneous measurements of the postsynaptic voltage responses and of the parallel changes in input conductance (Fig. 3) showed that the maximum increase in conductance coincided with the hIPSP, and the conductance fell rapidly to attain a value as low as $26 \pm 4 \%(n=9)$ of its maximum at the time of the peak GDPSP. The recovery of the conductance to its resting value was $90 \%$ complete at a time when the GDPSP had decayed to only $86 \pm 4 \%$ from its maximum.

To examine further the temporal relationships between the voltage and conductance changes associated with GDPSPs, we made experiments in which a second HFS train was applied with variable delays from the first. As shown in Figure 4, this resulted in a hyperpolarization that attained its maximum amplitude when evoked at the peak or late phase of the original GDPSP. With briefer delays, the hyperpolarizing effect of the second train was smaller. However, it is worth stressing that, in all five experiments of this kind, the depolarization during the initial phase of the GDPSP was slowed down markedly by the second train.

It is obvious that if the GDPSP were generated solely by a current across $\mathrm{GABA}_{\mathrm{A}}$ receptors under conditions of altered anion gradients, one would expect an enhanced depolarization, rather than a hyperpolarization, in response to further activation of the same synaptic inputs. The above findings indicate that, right after the HFS train, the membrane potential is close to (but slightly more positive than) $E_{\mathrm{GABA}-\mathrm{A}}$, but at peak and late GDPSP a level significantly more positive is attained. The evidence to be presented below suggests that the long-lasting depolarization is attributable to an activity-induced network-driven $\left[\mathrm{K}^{+}\right]_{\mathrm{o}}$ transient.

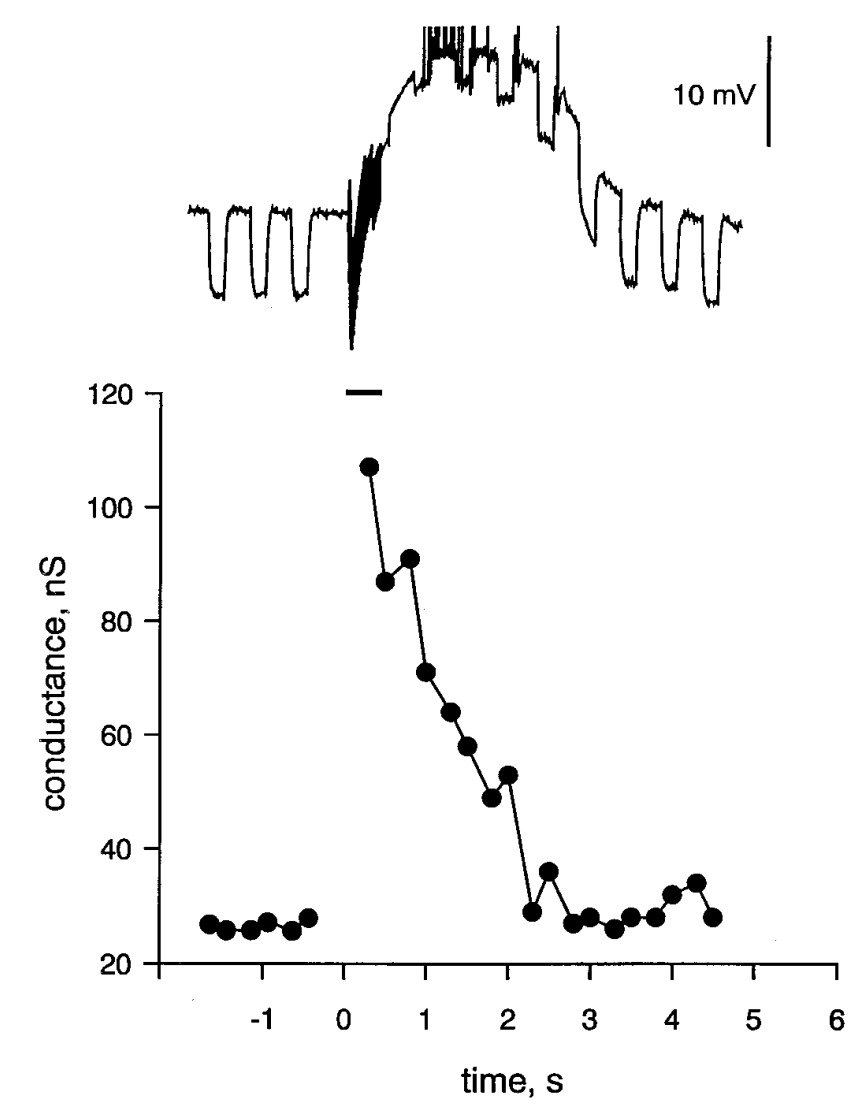

Figure 3. Temporal relationship between the GDPSP and the associated increase in input conductance. There is a rapid decrease in conductance that starts immediately after the onset of the GDPSP and declines almost to its resting level, whereas the GDPSP amplitude is still $\sim 75 \%$ of maximum (current-pulse amplitude, -200 pA.) 

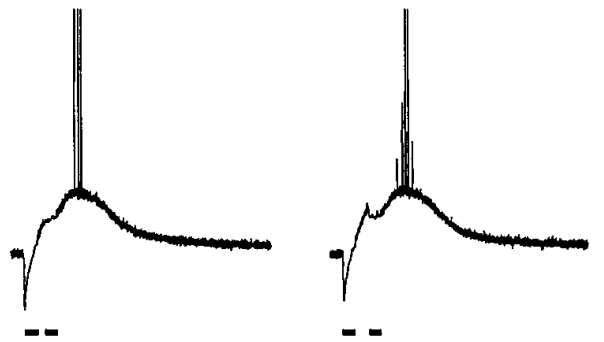

$10 \mathrm{mV} \frac{\bigsqcup_{2 \mathrm{~s}}}{\mathrm{~s}}$
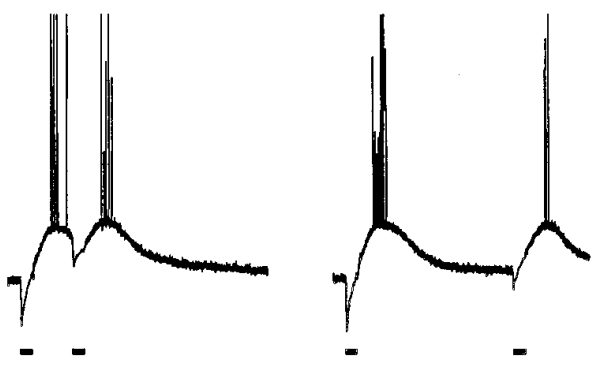

Figure 4. The postsynaptic voltage response to two HFS trains is affected by the timing of the second train. Note that the second train applied during the initial phase of the GDPSP leads to a slowing down of the depolarization, whereas the second train given while the GDPSP is at its peak or decaying phase induces a rapid hyperpolarization.

\section{The GDPSP/C is suppressed in a $\mathrm{CO}_{2} / \mathrm{HCO}_{3}^{-}$-free medium}

After a 30-60 min application of a nominally $\mathrm{CO}_{2} / \mathrm{HCO}_{3}^{-}$-free (HEPES-buffered) solution with $100 \% \mathrm{O}_{2}$ as the gas phase in the interface chamber, the GDPSP was strongly attenuated, to $10-$ $50 \%(n=4)$ of the control response (Fig. $5 A)$. This observation is consistent with a role for $\mathrm{HCO}_{3}^{-}$in the generation of the depolarizing response. That a full block was not always seen (compare top traces in Fig. $5 A$ ) may be attributable at least partly to production of $\mathrm{CO}_{2}$ (Voipio and Kaila, 1993).

In the absence of $\mathrm{HCO}_{3}^{-}$, fading of the hIPSC was strongly slowed down, resulting in voltages close to the resting potential in prolonged outwardly directed currents (Fig. $5 B$ ). There was a strong suppression (to $28 \pm 7 \% ; n=4$ ) of the GDPSC recorded at resting potential, and the apparent reversal potential (see above) of the peak GDPSC was $-60.5 \pm 1.3 \mathrm{mV}(n=4)$. All of the effects of the $\mathrm{CO}_{2} / \mathrm{HCO}_{3}^{-}$-free medium were reversible (data not shown).

Experiments with single stimuli applied at $0.5 \mathrm{~Hz}$ showed that the absence of $\mathrm{CO}_{2} / \mathrm{HCO}_{3}^{-}$did not have a consistent decremental effect on $\mathrm{GABA}_{\mathrm{A}}$ receptor-mediated transmission (compare Fig. 7). The above voltage-clamp experiments also clearly show that the inhibition of the GDPSP in the absence of $\mathrm{CO}_{2} / \mathrm{HCO}_{3}^{-}$ cannot be explained on the basis of a decrease in presynaptic excitability or a decrease in the input resistance $\left(R_{\mathrm{in}}\right)$ of the pyramidal neuron (cf. Grover et al., 1993). However, it is of interest to note here that, whereas a decrease in $R_{\text {in }}$ of $\sim 15 \%$ was observed in sharp microelectrode recordings after withdrawal of $\mathrm{CO}_{2} / \mathrm{HCO}_{3}^{-}$, the opposite was true for whole-cell experiments in which an increase in $R_{\text {in }}$ of $10-50 \%$ was seen. This implies that the resting conductance that is active under the two recording conditions differs not only in amount but also in the mechanisms involved (cf. Staley et al., 1992).
A

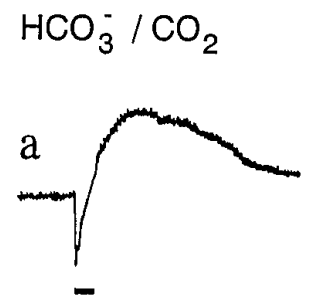

$$
\text { HEPES } / \mathrm{O}_{2}
$$
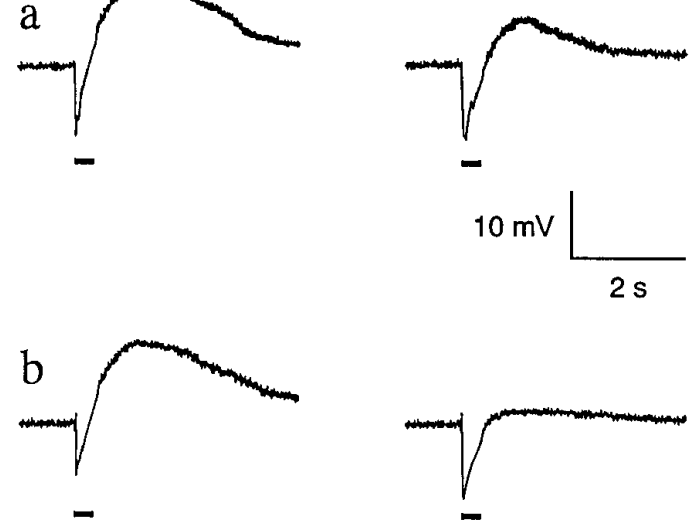

B
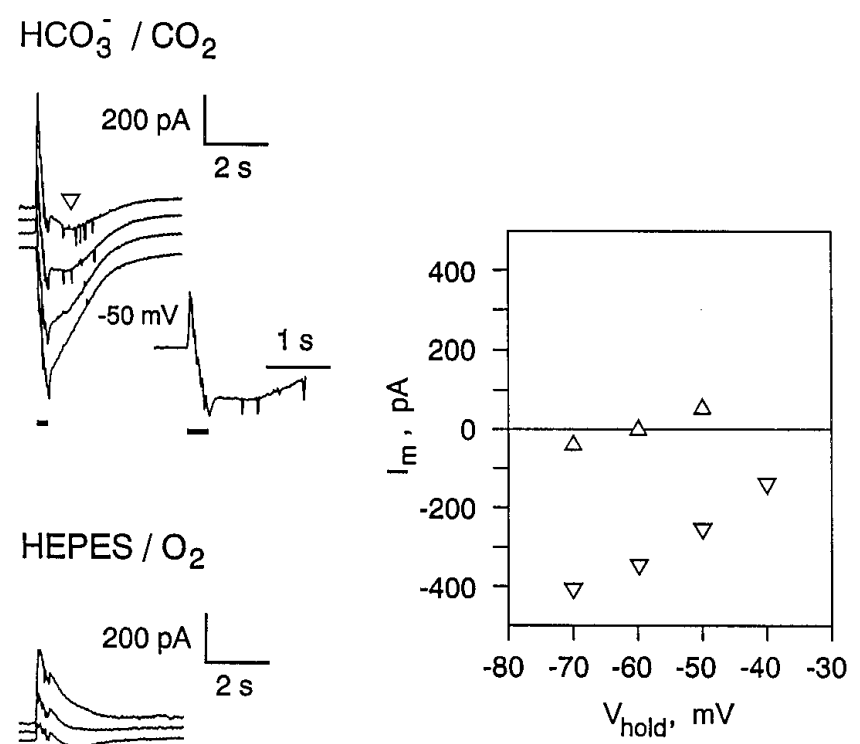

Figure 5. Dependence of GDPSP/C on the presence of $\mathrm{CO}_{2} / \mathrm{HCO}_{3}^{-} . A$, The GDPSP is suppressed (cell $a$ ) or blocked (cell $b$ ) in a nominally bicarbonate-free solution buffered with HEPES and equilibrated with $100 \% \mathrm{O}_{2} . B$, The GDPSC shows a dependence on bicarbonate similar to the GDPSP. Note that the hIPSC as measured at the resting level of this neuron $(-50 \mathrm{mV})$ is not suppressed in the HEPES $/ \mathrm{O}_{2}$ medium. Recordings at $-50 \mathrm{mV}$ are shown at an expanded time scale in both $A$ and $B$.

\section{The GDPSP/C is suppressed after global inhibition of intracellular (but not interstitial) carbonic anhydrase}

There are functionally distinct kinds of carbonic anhydrases that play a crucial role in activity-induced acid-base shifts in the brain parenchyma: in addition to intracellular isoforms located within certain neurons and glial cells, a distinct one seems to be responsible for rapid $\mathrm{CO}_{2}$ hydration/dehydration in the interstitial space (Chesler and Kaila, 1992). Therefore, we found it of interest to examine the effects of BA, a poorly permeant carbonic anhydrase inhibitor, and of EZA, a membrane-permeant inhibitor, on the 
A

control

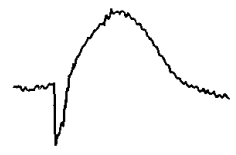

$10 \mu \mathrm{MBA}$
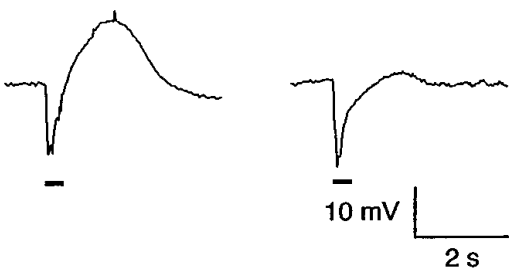

B

control

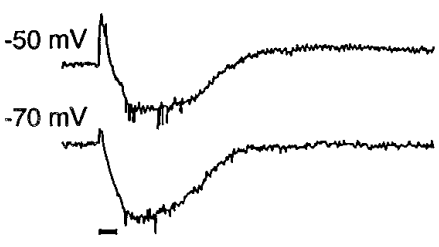

$50 \mu \mathrm{M}$ EZA

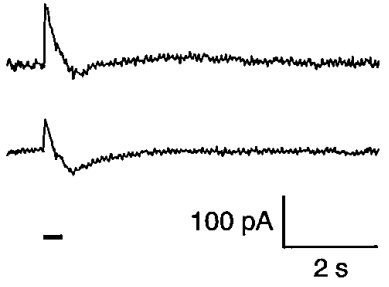

C
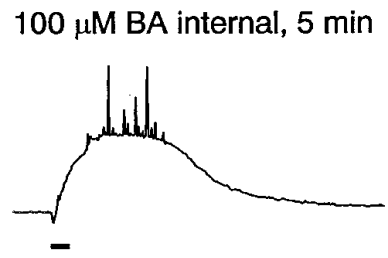

$30 \min$

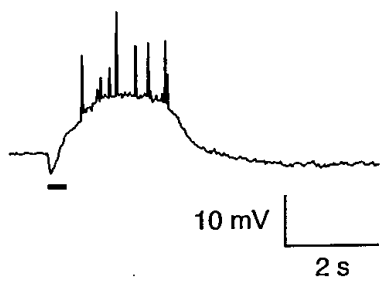

Figure 6. Effects of inhibitors of carbonic anhydrase on the GDPSP/C. $A$, Bath application of the impermeant carbonic anhydrase inhibitor benzolamide $(B A)$ has no effect on the GDPSP, whereas a subsequent exposure to the more lipophilic carbonic anhydrase blocker ethoxyzolamide $(E Z A)$ abolishes the GDPSP. $B$, The GDPSC is inhibited by bath-applied $E Z A$ $C$, Intracellular perfusion with $B A$ at high concentrations does not block the generation of the GDPSP.

postsynaptic responses (cf. Maren, 1977; Voipio et al., 1995). In nine slices examined, a full block of interstitial carbonic anhydrase with BA (10 $\mu \mathrm{M}$ applied for 30-60 min; Voipio et al., 1995) had no discernible effect on the GDPSP (Fig. $6 A$ ), whereas a subsequent exposure to $50 \mu \mathrm{m}$ EZA for $20-40$ min produced an attenuation of GDPSP and GDPSC similar to that observed in the absence of $\mathrm{CO}_{2} / \mathrm{HCO}_{3}^{-}$(Fig. $6 A, B$ ).

The above actions of EZA cannot be explained on the basis of a fall in interstitial $\mathrm{pH}\left(\mathrm{pH}_{\mathrm{o}}\right)$ as postulated for the suppressing action of acetazolamide by Grover et al. (1993), because both permeable and impermeable carbonic anhydrase inhibitors have a similar effect on $\mathrm{pH}_{\mathrm{o}}$, producing an extracellular acidosis of $\sim 0.1$ pH units (Voipio et al., 1995) (K. Kaila, P. Paalasmaa, and J. Voipio, unpublished results). Even more importantly, the above results show that, in contrast to the model by Staley et al. (1995), the interstitial space does not act as a compartment that provides for fast regeneration of the intracellular $\mathrm{CO}_{2} / \mathrm{HCO}_{3}^{-}$in the pyramidal neurons. In fact, as shown below, a fast replenishment of intracellular bicarbonate (whatever the source) within the pyramidal neuron is not necessary for the generation of the GDPSP/C.

\section{The GDPSP/C is not blocked by intracellular perfusion} of an inhibitor of carbonic anhydrase

Benzolamide is a highly potent drug used to inhibit various carbonic anhydrase isoforms with a concentration for halfmaximal inhibition in the nanomolar range (Maren, 1977). In sharp contrast to the obvious prediction of the Staley et al. (1995) model of GDPSP generation, internal perfusion with $100 \mu \mathrm{M}$ BA (even when applied for 70-80 min; $n=4$ ) had no detectable effect on the GDPSP. We also conducted five experiments with sharp microelectrodes containing $10 \mathrm{~mm}$ BA in the filling solution, but we failed to see any effect on the GDPSP.

It should be emphasized that the lack of effect on the GDPSP of BA applied intracellularly at concentrations that are at least four orders of magnitude higher than what is needed for complete carbonic anhydrase inhibition is not likely to be attributable to problems of diff usion, because this drug has a molecular weight of only 320 , and it is highly soluble in water. Hence, the above results indicate that an action on the pyramidal neuron is not responsible for the inhibition of the GDPSP/C by more lipophilic blockers of carbonic anhydrase inhibitors such as EZA (this study) and acetazolamide (Grover et al., 1993; Staley et al., 1995).

\section{Postsynaptic $\mathrm{Cl}^{-}$accumulation caused by an electroneutral, bicarbonate-dependent mechanism}

It has been demonstrated frequently that repetitive stimulation can lead to a decrease in the amplitude, and even to a change in the polarity, of single pulse-evoked fIPSPs, with no change in synaptic conductance (Wong and Watkins, 1982; Thompson and Gähwiler, 1989b). A widely accepted explanation to account for fIPSP fading and reversal of this kind is a postsynaptic uptake of $\mathrm{Cl}^{-}$and a consequent positive shift in the reversal potential of the $\mathrm{GABA}_{\mathrm{A}}$ receptor-mediated current (Kaila, 1994). To examine the mechanisms of the fast shift in $E_{\mathrm{GABA}-\mathrm{A}}$ that appears to take place at the initial phase of the GDPSP, we studied the influence of repetitive stimulation on the amplitude and polarity of fIPSCs in five neurons voltage-clamped at the level of their resting membrane potential. Figure 7 shows the results of a such an experiment. Single stimuli applied at a constant rate of $0.5 \mathrm{~Hz}$ produced outwardly directed fIPSCs with a constant amplitude. However, interposing a five-pulse train of stimuli at $100 \mathrm{~Hz}$ caused a marked (but reversible) suppression of the subsequent fIPSCs, and 10 pulses at $100 \mathrm{~Hz}$ caused an immediate (but reversible) change in their polarity. Another important finding in these experiments was that a fast HFS-induced redistribution of $\mathrm{Cl}^{-}$could not be observed in the absence of $\mathrm{HCO}_{3}^{-}$. In the experiment depicted in Figure 7, 5 or 10 pulses applied at $100 \mathrm{~Hz}$ in the HEPES-buffered solution had only a small effect on the amplitude of the fIPSCs and did not result in a change in their polarity.

Results of the above kind clearly suggest the presence of an electroneutral mechanism that is able to mediate a remarkably efficient accumulation of postsynaptic $\mathrm{Cl}^{-}$in response to an HFS train. Of course, this observation does not exclude a significant contribution of a bicarbonate-dependent channel-mediated net influx of $\mathrm{Cl}^{-}$to the fast positive shift in $E_{\mathrm{GABA}-\mathrm{A}}$ (cf. Kaila et al., 1989). However, a point worthy of emphasis is that the electroneutral mechanism also shows a dependence on $\mathrm{HCO}_{3}^{-}$. Below, we will present evidence for the view that the redistribution of $\mathrm{Cl}^{-}$is attributable in large part to an HFS-induced bicarbonatedependent increase in $\left[\mathrm{K}^{+}\right]_{0}$. 


\begin{abstract}
Figure 7. Stimulation-induced reversal of the polarity of fIPSC takes place in a voltage-clamped neuron and is dependent on the presence of $\mathrm{HCO}_{3}^{-}$. The cell was clamped at its resting potential, and single stimuli applied at a constant rate of $0.5 \mathrm{~Hz}$ produced outwardly directed fIPSCs with a constant amplitude. Interposing a five-pulse train of stimuli at $100 \mathrm{~Hz}$ $(5 / 100 \mathrm{~Hz})$ in the standard $\mathrm{HCO}_{3}^{-}$-containing solution caused a suppression of the subsequent fIPSCs, whereas 10 pulses at $100 \mathrm{~Hz}(10 / 100 \mathrm{~Hz})$ caused a change in their polarity. Similar brief HFS trains had little influence on fIPSCs in the nominally $\mathrm{HCO}_{3}^{-}$free HEPES-buffered solution. Data are taken from a continuous recording.
\end{abstract}
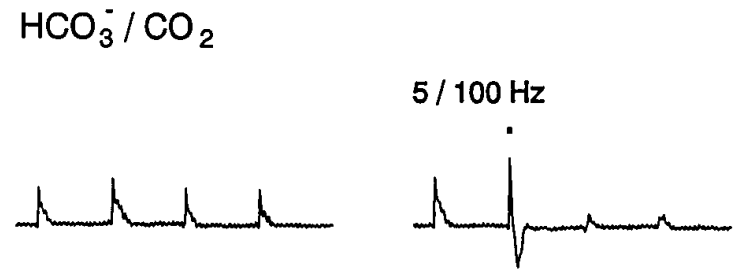

$\mathrm{HEPES} / \mathrm{O}_{2}$

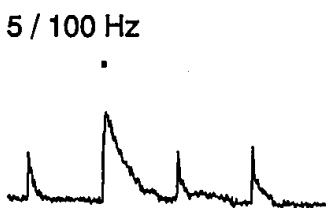

$10 / 100 \mathrm{~Hz}$

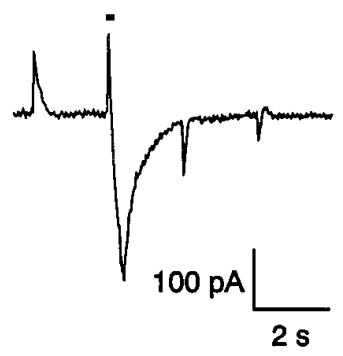

$10 / 100 \mathrm{~Hz}$

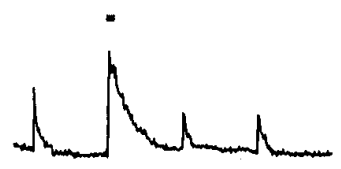

\section{The GDPSP is paralleled by a GABAergic increase in} extracellular $\mathrm{K}^{+}$

The intracellular $\mathrm{Cl}^{-}$concentration in pyramidal neurons appears to be set by plasmalemmal $\mathrm{K}^{+}-\mathrm{Cl}^{-}$cotransport (Thompson et al., 1988a,b; Thompson and Gähwiler, 1989a,b; Payne et al., 1996). This makes the reversal potential of $\mathrm{GABA}_{\mathrm{A}}$ receptormediated currents $\left(E_{\mathrm{GABA}-\mathrm{A}}\right)$ highly sensitive to changes in $\left[\mathrm{K}^{+}\right]_{\mathrm{o}}$, with an increase of $\mathrm{K}^{+}$leading to a positive shift (Kaila, 1994). Hence, it was of much interest to observe that the GDPSP was tightly linked to a stimulation-induced $\left[\mathrm{K}^{+}\right]_{\mathrm{o}}$ transient. The standard HFS train evoked a prompt increase in $\left[\mathrm{K}^{+}\right]_{\mathrm{o}}$ in both $\mathrm{s}$. pyramidale and s. radiatum.

Again, all of the experiments on $\left[\mathrm{K}^{+}\right]_{\mathrm{o}}$ shifts to be described in more detail were done in the presence of the ionotropic glutamate receptor antagonists. However, it is notable that, with the standard distance between the stimulating and recording electrodes $(\sim 500 \mu \mathrm{m})$, the application of glutamate antagonists produced only a modest decrease $(15-25 \% ; n=6)$ in the $\left[\mathrm{K}^{+}\right]_{\mathrm{o}}$ transient (Fig. $8 A$ ), whereas a subsequent application of $100 \mu \mathrm{M}$ picrotoxin resulted in a near-complete block (data not shown).

\section{Role of $\mathrm{HCO}_{3}^{-}$and carbonic anhydrase in the generation of the $\left[\mathrm{K}^{+}\right]_{0}$ transients}

Further evidence pointing to the involvement of $\left[\mathrm{K}^{+}\right]_{\mathrm{o}}$ transients in GDPSP generation was provided by the identical dependence of the two responses on the presence of $\mathrm{CO}_{2} / \mathrm{HCO}_{3}^{-}$and on a functional intracellular carbonic anhydrase activity. As illustrated in Figure $8 B$, in the HEPES medium the rise in $\left[\mathrm{K}^{+}\right]_{\mathrm{o}}$ was much smaller, $30-50 \%(n=5)$ of that seen in the control solution. The $\left[\mathrm{K}^{+}\right]_{\mathrm{o}}$ transient also was strongly attenuated in the presence of EZA, with a time course of inhibition identical to the effect of the drug on the GDPSP (data not shown). Bath-applied BA had no noticeable effect on the potassium transients.

\section{Spatial and temporal properties of the $\left[\mathrm{K}^{+}\right]_{0}$ transients}

The amplitude of the $\left[\mathrm{K}^{+}\right]_{\mathrm{o}}$ transient measured in s. radiatum at the standard distance of $500 \mu \mathrm{m}$ ranged between 2.3 and $4.5 \mathrm{~mm}$ $(n=15)$. Simultaneous measurements using two $\mathrm{K}^{+}$-selective microelectrodes showed that the peak amplitude of the $\left[\mathrm{K}^{+}\right]_{\mathrm{o}}$ transient in four of four experiments was slightly larger in $\mathrm{s}$. radiatum (mean increase $3.1 \pm 0.2 \mathrm{~mm}$ ) than in s. pyramidale $(1.9 \pm 0.3 \mathrm{~mm})$. This regional difference is identical to that seen with potassium transients associated with spontaneous GABAer-
A

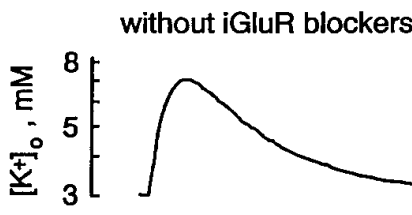

with iGluR blockers

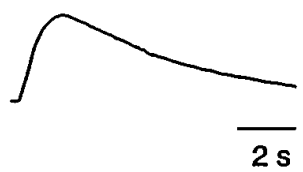

B

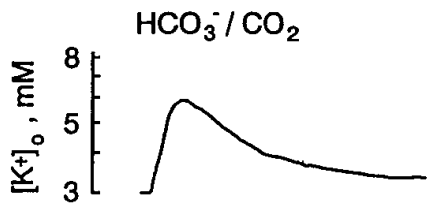

$\mathrm{HEPES} / \mathrm{O}_{2}$

Figure 8. The standard HFS trains evoke large GABAergic bicarbonatedependent $\left[\mathrm{K}^{+}\right]_{\mathrm{o}}$ transients in the CA1 region at the standard distance from the site of stimulation. $A$, The stimulation-induced $\left[\mathrm{K}^{+}\right]_{\mathrm{o}}$ transient is affected only slightly by the presence of ionotropic glutamate receptor agonists. (The left trace is the only recording shown in the present study that was obtained in the absence of ionotropic glutamate antagonists.) $B$, The stimulation-induced $\left[\mathrm{K}^{+}\right]_{0}$ is suppressed in the absence of $\mathrm{CO}_{2} / \mathrm{HCO}_{3}^{-}$.

gic events in slices exposed to 4-aminopyridine (Avoli et al., 1996). The amplitude of the GABAergic $\mathrm{K}^{+}$transient decreased steeply as a function of distance from the stimulating electrode, vanishing to zero at a distance of $\sim 1.5-2.0 \mathrm{~mm}$ (Fig. 9).

The $\left[\mathrm{K}^{+}\right]_{\mathrm{o}}$ transient in s. radiatum had a time to peak of $1.36 \pm$ $0.32 \mathrm{sec}(n=15)$. Simultaneous intracellular recordings of GDPSPs and associated $\left[\mathrm{K}^{+}\right]_{\mathrm{o}}$ shifts showed that, when evoked by various stimulation frequencies and stimulus train durations, the two responses had a closely matching time course (Fig. 10).

It is also evident from Figure 10 that a similar tight temporal coupling was true for responses involving a second HFS train, such as those examined earlier on (compare Fig. 4). Considering the idea that the $\left[\mathrm{K}^{+}\right]_{\mathrm{o}}$ shift is likely to play a significant direct role in the generation of the peak and late phase of the GDPSP (see Discussion), it is notable that in all simultaneous measurements the amplitude of the GDPSP showed a sub-Nernstian behavior with respect to the peak increase in $\mathrm{K}^{+}$. 

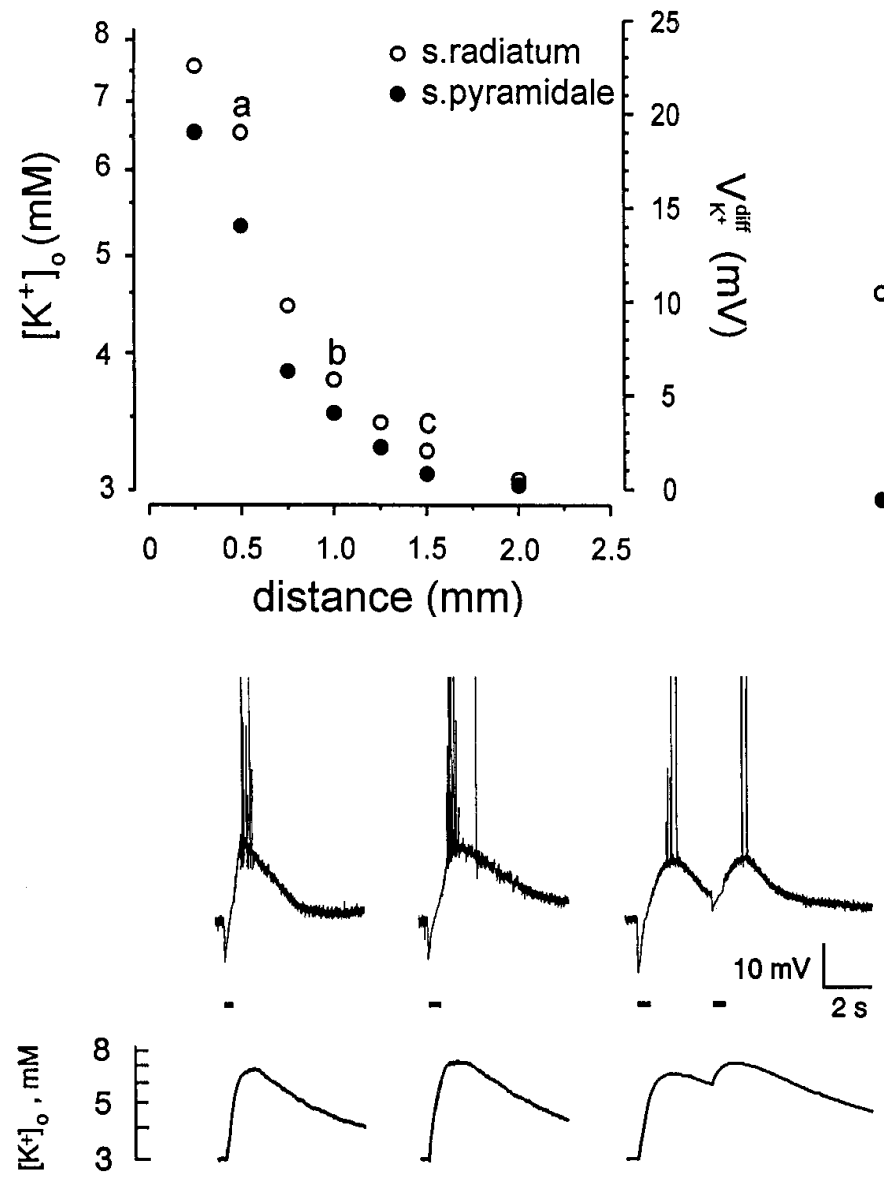

Figure 10. The GDPSP is closely paralleled by the activity-induced $\left[\mathrm{K}^{+}\right]_{\mathrm{o}}$ transient. Note the temporal coincidence of peak GDPSP and peak $\left[\mathrm{K}^{+}\right]_{\mathrm{o}}$ shift in responses evoked by both single and double HFS trains. To facilitate quantitative comparison, the voltage calibration applies for both the membrane voltage traces (top traces) and the $\mathrm{K}^{+}$electrode responses (bottom traces).

\section{Voltage responses and currents generated in glial cells in response to GABAergic $\left[\mathrm{K}^{+}\right]_{0}$ transient}

Temporal properties of the glial response

Changes in glial membrane potential have been used frequently to examine activity-induced changes in $\left[\mathrm{K}^{+}\right]_{\mathrm{o}}$, because it is known that the plasmalemma of these cells has a high selectivity to $\mathrm{K}^{+}$(Lothman and Somjen, 1975). Because the temporal resolution of ion-selective microelectrodes is rather limited (see Voipio et al., 1994), we made intracellular measurements from glial cells to gain further information about the time course of the $\left[\mathrm{K}^{+}\right]_{\mathrm{o}}$ shift, especially about its time of onset and rate of rise. The recordings were obtained by using both whole-cell pipettes and sharp microelectrodes from a total of six cells impaled in s. radiatum at the standard distance of $\sim 0.5 \mathrm{~mm}$ from the site of stimulation. The cells were identified on the basis of their rather negative membrane potential $(-80$ to $-90 \mathrm{mV})$ and the absence of any electrogenic response to depolarizing current pulses or to single extracellular stimuli.

The standard HFS train evoked a large depolarization (15-27 $\mathrm{mV}$ ) in all six of the cells examined (Fig. 11). The responses had a very fast onset, with a delay to $50 \%$ of maximum of only $94 \pm$ 9 msec. In view of the temporal properties of the GDPSP/C (see Table 1), it was of interest to note that at the time of the reversal of the hIPSP ( $\sim 290 \mathrm{msec}$ from the start of the train; see Table 1$)$,

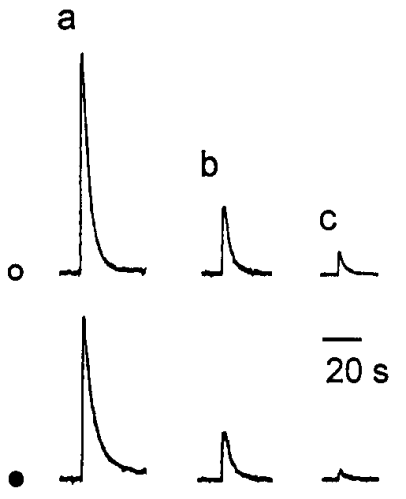

Figure 9. Spatial profile of the activityinduced $\left[\mathrm{K}^{+}\right]_{\mathrm{o}}$ shifts. Left, the peak amplitude of the $\left[\mathrm{K}^{+}\right]_{\mathrm{o}}$ shift is slightly larger in $\mathrm{s}$. radiatum than in $\mathrm{s}$. pyramidale, and it decays steeply as a function of distance from the site of recording. The plot shows peak responses in terms of the absolute level of $\left[\mathrm{K}^{+}\right]_{\mathrm{o}}$ attained as well as in terms of the response of the differential signal of the $\mathrm{K}^{+}$-selective microelectrode $\left(V_{\mathrm{K}+}^{\text {diff }}\right)$. Right, Specimen recordings related to data points indicated by $a-c$ in the plot.

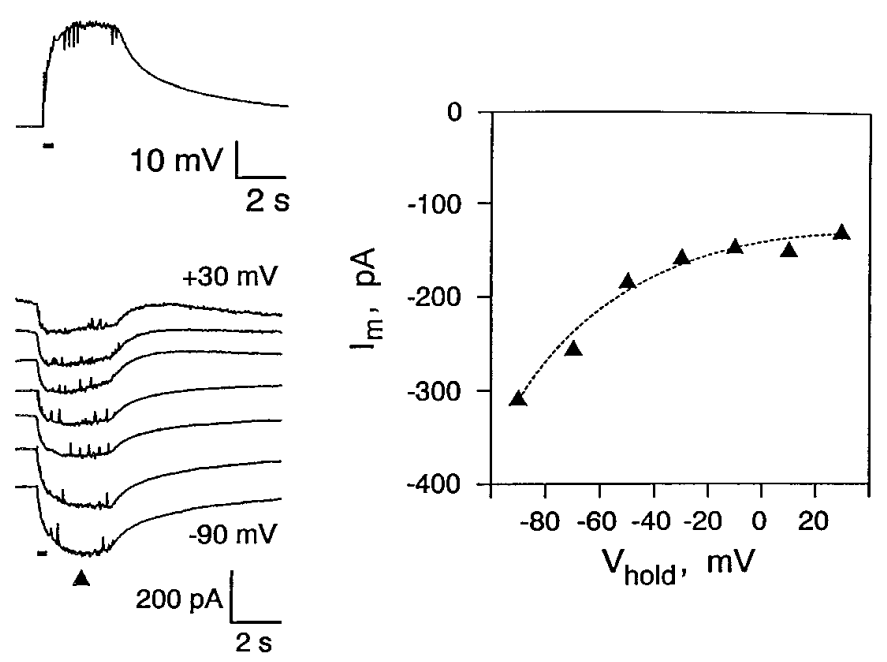

Figure 11. Voltage and current responses evoked by an HFS train in a glial cell under whole-cell recording conditions. The HFS train induces a fast depolarization or an inward current, which shows no tendency for reversal at voltages as positive as $+30 \mathrm{mV}$. The "asymptotic" behavior of the $I-V$ plot is what is to be expected from an inward current generated by an activity-induced $\left[\mathrm{K}^{+}\right]_{\mathrm{o}}$ transient (dashed curve fitted by eye).

the glial membrane potential changes had attained a mean value of $87 \%$ of maximum. These data indicate that, at the onset of the GDPSP, $\left[\mathrm{K}^{+}\right]_{\mathrm{o}}$ can reach a level of up to $7.4 \mathrm{~mm}$ within the interstitial space. As discussed below, such a rise in $\left[\mathrm{K}^{+}\right]_{\mathrm{o}}$ will lead to a pronounced inhibition of $\mathrm{Cl}^{-}$extrusion by $\mathrm{K}^{+}-\mathrm{Cl}^{-}$ cotransport in pyramidal neurons.

\section{$\mathrm{I}-\mathrm{V}$ relationships of glial current driven by a transient increase} in $\left[K^{+}\right]_{o}$

Figure 11 shows a whole-cell clamp experiment in which glial responses were evoked by the HFS train. As was to be expected from a current generated in response to a transient increase in $\left[\mathrm{K}^{+}\right]_{\mathrm{o}}$, the data yielded $I-V$ curves with a smooth "asymptotic" behavior, i.e., the inward current was diminished at progressively more positive voltages, but no reversal could be obtained even at voltages as positive as $+40 \mathrm{mV}$. This behavior is qualitatively similar to that of neuronal GDPSCs (see Fig. 2), which agrees with the idea that a direct depolarizing action of the $\left[\mathrm{K}^{+}\right]_{\mathrm{o}}$ transient plays an important role in the generation of the GDPSP/C. 


\section{DISCUSSION}

Experiments on crayfish muscle fibers originally showed that a depolarizing effect mediated by $\mathrm{GABA}_{\mathrm{A}}$ receptors does not necessarily imply that $\mathrm{Cl}^{-}$is actively transported into the postsynaptic cell but that $\mathrm{HCO}_{3}^{-}$can act as a carrier of depolarizing current (Kaila and Voipio, 1987; Kaila et al., 1989). A study on neocortical neurons showed that an $\mathrm{HCO}_{3}^{-}$versus $\mathrm{Cl}^{-}$permeability ratio of $\sim 0.2$ (cf. Bormann et al., 1987) accounts for a +10 to $+15 \mathrm{mV}$ deviation of the reversal potential of $\mathrm{GABA}_{\mathrm{A}}$ receptor-mediated fIPSPs from the $\mathrm{Cl}^{-}$equilibrium potential $\left(E_{\mathrm{Cl}}\right)$ (Kaila et al., 1993). In view of the fact that all kinds of $\mathrm{GABA}_{\mathrm{A}}$ receptors studied to date have an $\mathrm{HCO}_{3}^{-} / \mathrm{Cl}^{-}$permeability ratio of $\sim 0.2-0.4$ (Kaila, 1994) (see also Fatima-Shad and Barry, 1993), the reversal potential of fIPSPs in hippocampal pyramidal neurons is also likely to be more positive than $E_{\mathrm{Cl}}$. However, it is readily evident from quantitative considerations based on the Goldman-Hodgkin-Katz voltage equation (Hille, 1992) that the extremely positive reversal potential of the GDPSCs examined presently cannot be explained as an immediate consequence of a $\mathrm{HCO}_{3}^{-}$permeability (see Fig. 4 in Kaila and Voipio, 1990).

The apparent paradox above is resolved by the present experiments, which indicate that $E_{\mathrm{GABA}-\mathrm{A}}$ remains negative with respect to the peak GDPSP, and, as discussed below (Fig. 12), a depolarizing mechanism other than a direct $\mathrm{GABA}_{\mathrm{A}}$ receptormediated input to the pyramidal neuron has to be involved.

\section{Intrapyramidal and interstitial carbonic anhydrase are not needed for GDPSP/C generation}

To explain the biphasic response evoked by tonic activation of $\mathrm{GABA}_{\mathrm{A}}$ receptors, Staley et al. (1995) suggested that a large gain of internal $\mathrm{Cl}^{-}$and a modest net loss of $\mathrm{HCO}_{3}^{-}$take place, leading to a fast depolarizing shift in $E_{\mathrm{GABA}-\mathrm{A}}$. The inhibitory action of acetazolamide was accounted for by a block of the carbonic anhydrase activity within the pyramidal neuron (cf. Pasternack et al., 1993) and in the interstitial space (cf. Kaila et al., 1992).

The results of the present study do not support a mechanism of the above kind. First, inhibition of interstitial carbonic anhydrase by bath-applied benzolamide did not suppress the GDPSP. Second, there was no suppression of the GDPSP after internal perfusion of the pyramidal neuron with benzolamide. These results indicate that the critical carbonic anhydrase activity that is sensitive to bath-applied EZA (see Fig. 6) is located in an intracellular compartment other than that of the target neuron.

A further finding central to the scheme proposed by Staley et al. (1995) was that amiloride blocked GDPSP generation, an effect thought to be attributable to a fall in the postsynaptic intracellular $\mathrm{HCO}_{3}^{-}$in response to a block of $\mathrm{Na}^{+} / \mathrm{H}^{+}$exchange. However, the $\mathrm{Na}^{+} / \mathrm{H}^{+}$exchanger in pyramidal neurons is known to be insensitive to amiloride and its derivatives (Raley-Susman et al., 1993; Schwiening and Boron, 1994; Bevensee et al., 1996). Amiloride is not a specific inhibitor of $\mathrm{Na}^{+} / \mathrm{H}^{+}$exchange, and the results obtained by Staley et al. (1995) may well have been caused by a direct effect of the drug on neuronal excitability (cf. Benos, 1982; Tang et al., 1988).

\section{Activity-dependent $\left[\mathrm{K}^{+}\right]_{\mathrm{o}}$ transients generated by the GABAergic interneuronal network}

An intriguing observation made presently was that large stimulation-induced $\left[\mathrm{K}^{+}\right]_{\mathrm{o}}$ transients can be evoked in the CA1 region in the presence of antagonists of ionotropic glutamate

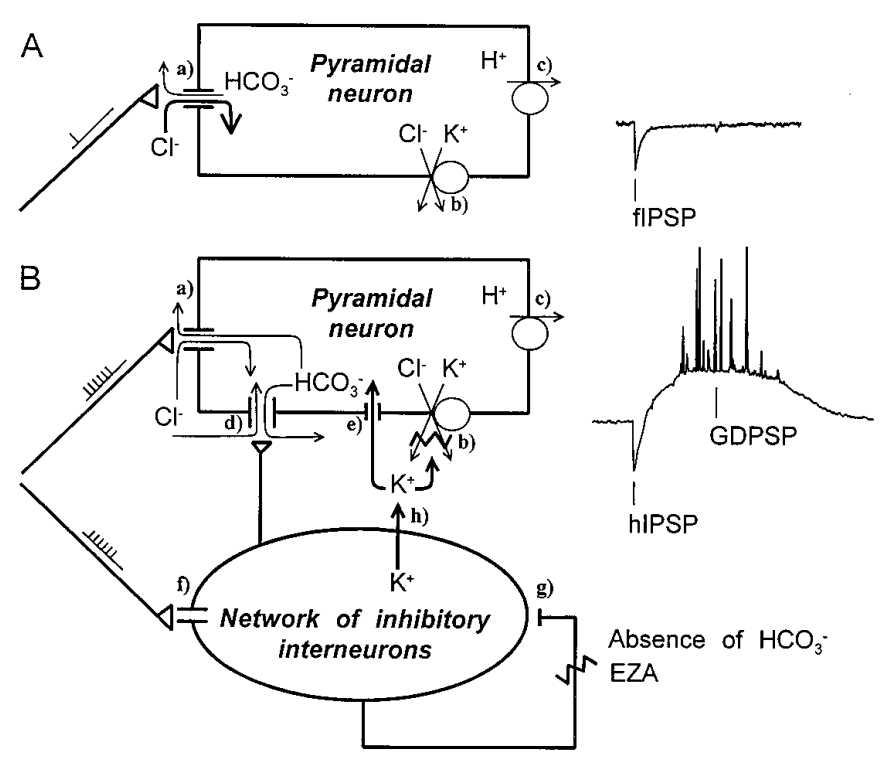

Figure 12. Mechanisms of $\mathrm{GABA}_{\mathrm{A}}$ receptor-dependent postsynaptic responses evoked in a pyramidal neuron by a single stimulus $(A)$ and by an HFS train $(B) . A$, Under resting conditions $\mathrm{Cl}^{-}$is expelled on a $\mathrm{K}^{+}-\mathrm{Cl}^{-}$cotransporter $(b)$, and intracellular $\mathrm{HCO}_{3}^{-}$is accumulated by an acid-extruding mechanism $(c)$. Because most of the postsynaptic current is carried by $\mathrm{Cl}^{-}$, the activation of $\mathrm{GABA}_{\mathrm{A}}$ receptors by a single stimulus leads to a hyperpolarizing fIPSP. $B$, An HFS train evokes GABA receptor-mediated responses in both the pyramidal neuron and the local inhibitory network $(a, f)$. The rise in $\left[\mathrm{K}^{+}\right]_{\mathrm{o}}$ triggered by the activity of the inhibitory network has two consequences. (1) The increase in $\left[\mathrm{K}^{+}\right]_{\mathrm{o}}(h)$ inhibits $\mathrm{Cl}^{-}$extrusion by the $\mathrm{K}^{+}-\mathrm{Cl}^{-}$cotransporter (zigzag line), leading to an accumulation of $\mathrm{Cl}^{-}$and to a positive shift in $E_{\mathrm{GABA}-\mathrm{A}}$, while the GABA $_{\mathrm{A}}$ ergic inputs $(a, d)$ to the pyramidal neuron are active. This produces the initial phase of the GDPSP that is associated with a large increase in conductance. (2) The $\left[\mathrm{K}^{+}\right]_{\mathrm{o}}$ transient outlasts the $\mathrm{GABA}_{\mathrm{A}}$ receptor-mediated conductance in the pyramidal cell and has a direct depolarizing action that is mediated by the plasmalemmal $\mathrm{K}^{+}$conductance $(e)$. The direct depolarizing action of the $\left[\mathrm{K}^{+}\right]_{\mathrm{o}}$ transient starts rather soon after the onset of the GDPSP, which leads to a membrane potential that is progressively more positive than $E_{\mathrm{GABA}-\mathrm{A}}$ (compare with Fig. 4). The present results also indicate that the excitatory coupling within the interneuronal network $(g)$ is dependent on the availability of $\mathrm{HCO}_{3}^{-}$and is suppressed (zigzag line) both in the nominal absence of bicarbonate as well as in the presence of a membrane-permeant inhibitor of carbonic anhydrase $(E Z A)$.

receptors. The spatial profile (see Fig. 9) and the sensitivity of these $\left[\mathrm{K}^{+}\right]_{\mathrm{o}}$ shifts to picrotoxin suggest that they are generated by a local GABAergic interneuronal network.

The conclusion that intense interneuronal activity is capable of producing prominent shifts in $\left[\mathrm{K}^{+}\right]_{\mathrm{o}}$ is not a novel one. Experiments on brain slices exposed to the convulsant 4-aminopyridine have demonstrated spontaneous "waves" of GABAergic activity (Aram et al., 1991; Perreault and Avoli, 1992), which are associated with substantial $\left[\mathrm{K}^{+}\right]_{\mathrm{o}}$ shifts and with long-lasting neuronal depolarizations (Avoli et al., 1996; Lamsa and Kaila, 1997) (see also Barolet and Morris, 1991).

A withdrawal of $\mathrm{CO}_{2} / \mathrm{HCO}_{3}^{-}$as well as the application of a membrane-permeant carbonic anhydrase inhibitor (EZA) led to an attenuation of the HFS-induced $\left[\mathrm{K}^{+}\right]_{\mathrm{o}}$ transients (this study) and of spontaneous 4-aminopyridine-induced $\left[\mathrm{K}^{+}\right]_{\mathrm{o}}$ shifts (Lamsa and Kaila, 1997). These findings strongly suggest that the mutual $\mathrm{GABA}_{\mathrm{A}}$ receptor-mediated excitatory coupling among inhibitory interneurons depends on a functional intracellular $\mathrm{CO}_{2} / \mathrm{HCO}_{3}^{-}$buffer. This is also consistent with the observations that a $\mathrm{GABA}_{\mathrm{A}}$ receptor-mediated neuronal efflux of $\mathrm{HCO}_{3}^{-}$takes 
place both in response to HFS in area CA1 (Kaila et al., 1992; Taira et al., 1995; Voipio et al., 1995) and in the presence of 4-aminopyridine-induced spontaneous activity (Lamsa and Kaila, 1997).

\section{Postsynaptic $\mathrm{Cl}^{-}$accumulation in response to the HFS-induced increase in $\left[\mathrm{K}^{+}\right]_{\text {o }}$}

Experiments done under voltage-clamp conditions showed that a rather small number of stimuli given at a high frequency are sufficient to produce a large positive shift in $E_{\mathrm{GABA}-\mathrm{A}}$ (compare Fig. 7). This indicates the presence of a postsynaptic mechanism that leads to an accumulation of $\mathrm{Cl}^{-}$, which is not driven by the membrane potential. It is likely that, after an HFS train, the activity-induced increase in $\left[\mathrm{K}^{+}\right]_{\mathrm{o}}$ results in an inhibition, or reversal, of $\mathrm{Cl}^{-}$extrusion on postsynaptic $\mathrm{K}^{+}-\mathrm{Cl}^{-}$cotransport (see Fig. 12; Thompson and Gähwiler, 1989a; Jensen et al., 1993; Payne et al., 1996).

The present results indicate that the HFS train evokes a rise in $\left[\mathrm{K}^{+}\right]_{\mathrm{o}}$ up to a level of $8.5 \mathrm{~mm}$, and, at the time of the onset of the GDPSP, $\left[\mathrm{K}^{+}\right]_{\mathrm{o}}$ can reach a level of $7.4 \mathrm{~mm}$. Even in the absence of a channel-mediated $\mathrm{Cl}^{-}$load (see Kaila et al., 1989) and assuming that the $1: 1 \mathrm{~K}^{+}-\mathrm{Cl}^{-}$cotransport mechanism rapidly attains its equilibrium, these $\left[\mathrm{K}^{+}\right]_{\mathrm{o}}$ transients can induce an increase in the internal $\mathrm{Cl}^{-}$concentration from $\sim 4 \mathrm{mM}$ (see Materials and Methods; Kaila et al., 1993) to $10-11 \mathrm{~mm}$. This is sufficient to account for a +16 to $+18 \mathrm{mV}$ shift in $E_{\text {GABA-A }}$ (cf. Kaila and Voipio, 1990) and for the time-dependent positive shift of the early $I-V$ curves that show outward rectification (see Fig. 2B).

In a recent paper on hippocampal slices exposed to 4aminopyridine, Perkins and Wong (1996) have suggested that the late phase of "giant GABA-mediated postsynaptic currents" (GP$\mathrm{SCs}$ ) in CA3 pyramidal neurons might be mediated by GABA receptors that are preferentially selective for $\mathrm{HCO}_{3}^{-}$. When recorded with pipettes containing a high- $\mathrm{Cl}^{-}$, low- $\mathrm{HCO}_{3} /$ low $\mathrm{pH}$ solution, the late "GABA ${ }_{\mathrm{D}}$ " current was reported to reverse at a more negative level than the initial $\mathrm{GABA}_{\mathrm{A}}$ response. However, even when allowing for deviations of the true intracellular anion concentrations from those within the whole-cell electrodes, we have been unable to fit the above observations with any anionic permeability ratio. Perhaps more importantly, the "GABA current had a linear $I-V$ with a true reversal at approximately -67 $\mathrm{mV}$ under standard conditions, which is a far too negative level to explain depolarizations of the kind studied in the present work.

\section{The increase in $\left[\mathrm{K}^{+}\right]_{0}$ has a direct depolarizing action}

When a second train of stimuli was applied at the peak of the GDPSP, a prompt hyperpolarization was observed (compare Fig. 4). This provides direct evidence that $E_{\mathrm{GABA}-\mathrm{A}}$ remains more negative than the membrane potential at the time of maximum depolarization. The nonanionic mechanism that seems to play a crucial role in the generation of the GDPSP is a direct depolarizing action of the HFS-induced $\left[\mathrm{K}^{+}\right]_{\mathrm{o}}$ shift. The peak amplitudes of the GDPSPs showed a consistent (but sub-Nernstian) relationship to the peak $\left[\mathrm{K}^{+}\right]_{\mathrm{o}}$ shifts, and, as already discussed, the $I-V$ characteristics of the late GDPSC (and of the glial responses; see Fig. 11) are consistent with a delayed, $\left[\mathrm{K}^{+}\right]_{\mathrm{o}}$-mediated effect. Formally, the $I-V$ characteristics of a $\mathrm{K}^{+}$-evoked depolarizing current $\left(I_{\mathrm{K}}\right)$ can be derived easily from the Goldman-HodgkinKatz constant field current equation:

$$
I_{\mathrm{K}}=F^{2} R^{-1} T^{-1} V_{\mathrm{m}} P_{\mathrm{K}} \frac{\left[K^{+}\right]_{\mathrm{o}}-\left[K^{+}\right]_{\mathrm{i}} e^{k V_{\mathrm{m}}}}{1-e^{k V_{\mathrm{m}}}}
$$

where $k=F R^{-1} T^{-1},\left[\mathrm{~K}^{+}\right]_{\mathrm{i}}$ is the intracellular $\mathrm{K}^{+}$concentration, and $V_{\mathrm{m}}, P_{\mathrm{K}}, F, R$, and $T$ have their usual meaning. The dependence of $I_{\mathrm{K}}$ on $\left[\mathrm{K}^{+}\right]_{\mathrm{o}}$ is obtained by differentiation with respect to $\left[\mathrm{K}^{+}\right]_{\mathrm{o}}$. Assuming that the cell is under voltage clamp,

$$
\frac{\partial I_{\mathrm{K}}}{\partial\left[K^{+}\right]_{\mathrm{o}}}=F^{2} R^{-1} T^{-1} P_{\mathrm{K}} \frac{V_{\mathrm{m}}}{1-e^{k V_{\mathrm{m}}}} .
$$

Because $V_{\mathrm{m}} /\left(1-e^{k V_{\mathrm{m}}}\right)$ is always negative, $\partial I_{\mathrm{K}} / \partial\left[\mathrm{K}^{+}\right]_{\mathrm{o}}$ is also negative at any $V_{\mathrm{m}}$; i.e., a rise in $\left[\mathrm{K}^{+}\right]_{\mathrm{o}}$ causes an inward current at any $V_{\mathrm{m}}$. In addition, $V_{\mathrm{m}} /\left(1-e^{k V_{\mathrm{m}}}\right)$ approaches asymptotically zero at positive values of $V_{\mathrm{m}}$.

Strongly depolarizing GABAergic postsynaptic responses are associated with certain kinds of long-term changes in synaptic efficacy (Collin et al., 1995), in the generation of epileptiform activity (Taira et al., 1997) (see also Stasheff et al., 1993), and in the immature nervous system (Cherubini et al., 1991). It will be interesting to see in future work whether, and to what extent, activity-induced $\left[\mathrm{K}^{+}\right]_{\mathrm{o}}$ shifts are involved in the diverse phenomena that involve long-lasting GABAergic depolarizing responses in the developing and mature brain. Information on excitatory $\mathrm{GABA}_{\mathrm{A}}$ receptor-mediated responses is also likely to shed light on the mechanisms of functional coupling within the inhibitory interneuronal network and of its oscillatory properties (cf. Michelson and Wong, 1994; Whittington et al., 1995; Traub et al., 1996; Lamsa and Kaila, 1997).

\section{REFERENCES}

Aram JA, Michelson HB, Wong RKS (1991) Synchronized GABAergic IPSPs recorded in the neocortex after blockade of synaptic transmission mediated by excitatory amino acids. J Neurophysiol 65:1034-1041.

Avoli M, Louvel J, Kurcewicz I, Pumain R, Barbarosie M (1996) Extracellular free potassium and calcium during synchronous activity induced by 4-aminopyridine in the juvenile rat hippocampus. J Physiol (Lond) 493:707-717.

Barolet AW, Morris ME (1991) Changes in extracellular $\mathrm{K}^{+}$evoked by GABA, THIP, and baclofen in the guinea-pig hippocampal slice. Exp Brain Res 84:591-598.

Benos DJ (1982) Amiloride: a molecular probe of sodium transport in tissues and cells. Am J Physiol 242:C131-C145.

Bevensee MO, Cummins TR, Haddad GG, Boron WF, Boyarski G (1996) $\mathrm{pH}$ regulation in single CA1 neurons acutely isolated from the hippocampi of immature and mature rats. J Physiol (Lond) 494:315-328.

Blanton MG, Loturco JJ, Kriegstein AR (1989) Whole cell recording from neurons in slices of reptilian and mammalian cerebral cortex. J Neurosci Methods 30:203-210.

Bormann J, Hamill OP, Sakmann B (1987) Mechanism of anion permeation through channels gated by glycine and $\gamma$-aminobutyric acid in mouse cultured spinal neurones. J Physiol (Lond) 385:243-286.

Cherubini E, Gaiarsa JL, Ben-Ari Y (1991) GABA: an excitatory transmitter in early postnatal life. Trends Neurosci 14:515-519.

Chesler M, Kaila K (1992) Modulation of $\mathrm{pH}$ by neuronal activity. Trends Neurosci 15:396-402.

Cole AE, Nicoll RA (1984) Characterization of a slow cholinergic postsynaptic potential recorded in vitro from rat hippocampal pyramidal cells. J Physiol (Lond) 352:173-188.

Collin C, Devane WA, Dahl D, Lee C-J, Axelrod J, Alkon DL (1995) Long-term synaptic transformation of hippocampal CA1 $\gamma$ aminobutyric acid synapses and the effect of anandamide. Proc Natl Acad Sci USA 92:10167-10171.

Davies CH, Collingridge GL (1993) The physiological regulation of synaptic inhibition by $\mathrm{GABA}_{\mathrm{B}}$ autoreceptors in rat hippocampus. J Physiol (Lond) 472:245-265.

Fatima-Shad K, Barry PH (1993) Anion permeation in GABA- and glycine-gated channels of mammalian cultured hippocampal neurons. Proc R Soc Lond [Biol] 253:69-75.

Grover LM, Lambert NA, Schwartzkroin PA, Teyler TJ (1993) Role of $\mathrm{HCO}_{3}^{-}$ions in depolarizing $\mathrm{GABA}_{\mathrm{A}}$ receptor-mediated responses in pyramidal cells of rat hippocampus. J Neurophysiol 69:1541-1555. 
Hille B (1992) Ionic currents of excitable membranes, 2nd Ed. Sunderland, MA: Sinauer.

Jensen MS, Cherubini E, Yaari Y (1993) Opponent effects of potassium on $\mathrm{GABA}_{\mathrm{A}}$-mediated postsynaptic inhibition in the rat hippocampus. J Neurophysiol 69:764-771.

Kaila K (1994) Ionic basis of $\mathrm{GABA}_{\mathrm{A}}$ receptor channel function in the nervous system. Prog Neurobiol 42:489-537.

Kaila K, Voipio J (1987) Postsynaptic fall in intracellular $\mathrm{pH}$ induced by GABA-activated bicarbonate conductance. Nature 330:163-165.

Kaila K, Voipio J (1990) GABA-activated bicarbonate conductance: influence on $E_{\mathrm{GABA}}$ and on postsynaptic $\mathrm{pH}$ regulation. In: Chloride channels and carriers in nerve, muscle and glial cells (AlvarezLeefmans FJ, Russell JM, eds), pp 331-353. New York: Plenum.

Kaila K, Pasternack M, Saarikoski J, Voipio J (1989) Influence of GABA-gated bicarbonate conductance on membrane potential, current, and intracellular chloride in crayfish muscle fibres. J Physiol (Lond) 416:161-181.

Kaila K, Paalasmaa P, Taira T, Voipio J (1992) pH transients due to monosynaptic activation of $\mathrm{GABA}_{\mathrm{A}}$ receptors in rat hippocampal slices. NeuroReport 3:105-108.

Kaila K, Voipio J, Paalasmaa P, Pasternack M, Deisz RA (1993) The role of bicarbonate in $\mathrm{GABA}_{\mathrm{A}}$ receptor-mediated IPSPs in rat neocortical neurons. J Physiol (Lond) 464:273-289.

Kaila K, Smirnov S, Taira T, Voipio J (1995) Both anionic and cationic mechanisms contribute to $\mathrm{GABA}_{\mathrm{A}}$ receptor-mediated depolarizing synaptic responses in CA1 pyramidal neurons. Soc Neurosci Abstr 21:244.4.

Lambert N, Grover L (1995) The mechanism of biphasic GABA responses. Science 269:928-929.

Lamsa K, Kaila K (1997) Ionic mechanisms of spontaneous GABAergic events in rat hippocampal slices exposed to 4-aminopyridine. J Neurophysiol, in press.

Lothman EW, Somjen GG (1975) Extracellular potassium activity, intracellular and extracellular potential responses in the spinal cord. J Physiol (Lond) 252:115-136.

Maren TH (1977) Use of inhibitors in physiological studies of carbonic anhydrase. Am J Physiol 232:F291-F297.

Michelson HB, Wong RKS (1994) Synchronization of inhibitory neurones in the guinea-pig hippocampus in vitro. J Physiol (Lond) 477:35-45.

Nathan T, Jensen MS, Lambert JDC (1990) The slow inhibitory postsynaptic potential in rat hippocampal neurons is blocked by intracellular injection of QX-314. Neurosci Lett 110:309-313.

Nicoll RA, Malenka RC, Kauer JA (1990) Functional comparison of neurotransmitter receptor subtypes in mammalian central nervous system. Physiol Rev 70:513-565.

Pasternack M, Voipio J, Kaila K (1993) Intracellular carbonic anhydrase activity and its role in GABA-induced acid transients in isolated rat hippocampal pyramidal neurones. Acta Physiol Scand 148:229-231.

Payne JA, Stevenson TJ, Donaldson LF (1996) Molecular characterization of a putative $\mathrm{K}-\mathrm{Cl}$ cotransporter in rat brain. J Biol Chem 271:16247-16252.

Perkins KL, Wong RKS (1996) Ionic basis of the postsynaptic depolarizing GABA response in hippocampal pyramidal cells. J Neurophysiol 76:3886-3894.

Perreault P, Avoli M (1992) 4-Aminopyridine-induced epileptiform activity and a GABA-mediated long-lasting depolarization in the rat hippocampus. J Neurosci 12:104-115.
Raley-Susman KM, Sapolsky RM, Kopito RR (1993) $\mathrm{Cl}^{-} / \mathrm{HCO}_{3}^{-}$exchange function differs in adult and fetal rat hippocampal neurons. Brain Res 614:308-314.

Schwiening CJ, Boron WF (1994) Regulation of intracellular $\mathrm{pH}$ in pyramidal neurones from the rat hippocampus by $\mathrm{Na}^{+}$-dependent $\mathrm{Cl}^{-}-\mathrm{HCO}_{3}^{-}$exchange. J Physiol (Lond) 475:59-67.

Staley KJ, Otis TS, Mody I (1992) Membrane properties of dentate gyrus granule cells: comparison of sharp microelectrode and whole-cell recordings. J Neurophysiol 67:1346-1358.

Staley KJ, Soldo BL, Proctor WR (1995) Ionic mechanisms of neuronal excitation by inhibitory GABA $_{\mathrm{A}}$ receptors. Science 269:977-981.

Stasheff SF, Mott DD, Wilson WA (1993) Axon terminal hyperexcitability associated with epileptogenesis in vitro. II. Pharmacological regula-

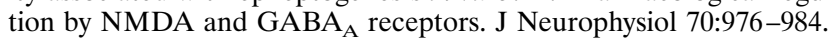

Taira T, Paalasmaa P, Voipio J, Kaila K (1995) Relative contributions of excitatory and inhibitory neuronal activity to alkaline transients evoked by stimulation of Schaffer collaterals in the rat hippocampal slice. J Neurophysiol 74:643-649.

Taira T, Lamsa K, Kaila K (1997) Post-tetanic excitation mediated by $\mathrm{GABA}_{\mathrm{A}}$ receptors in rat CA1 pyramidal neurons. J Neurophysiol 77:2213-2218.

Tang C-M, Presser F, Morad M (1988) Amiloride selectively blocks the low threshold (T) calcium channel. Science 240:213-215.

Thompson SM, Gähwiler BH (1989a) Activity-dependent disinhibition. II. Effects of extracellular potassium, furosemide, and membrane potential on $\mathrm{E}_{\mathrm{Cl}^{-}}$in hippocampal CA3 neurons. J Neurophysiol 61:512-523.

Thompson SM, Gähwiler BH (1989b) Activity-dependent disinhibition. I. Repetitive stimulation reduces IPSP driving force and conductance in the hippocampus in vitro. J Neurophysiol 61:501-511.

Thompson SM, Deisz RA, Prince DA (1988a) Outward chloride/cation co-transport in mammalian cortical neurons. Neurosci Lett 89:49-54.

Thompson SM, Deisz RA, Prince DA (1988b) Relative contributions of passive equilibrium and active transport to the distribution of chloride in mammalian cortical neurons. J Neurophysiol 60:105-124.

Traub RD, Whittington MA, Colling SB, Buzsaki G, Jefferys JGR (1996) Analysis of gamma rhythms in the rat hippocampus in vitro and in vivo. J Physiol (Lond) 493:471-484.

Voipio J, Kaila K (1993) Interstitial $\mathrm{PCO}_{2}$ and $\mathrm{pH}$ in rat hippocampal slices measured by means of a novel fast $\mathrm{CO}_{2} / \mathrm{H}^{+}$-sensitive microelectrode based on a PVC-gelled membrane. Pflügers Arch 423:193-201.

Voipio J, Pasternack M, MacLeod K (1994) Ion-sensitive microelectrodes. In: Microelectrode techniques, the Plymouth workshop handbook, 2nd Ed (Ogden D, ed), pp 275-316. Cambridge, UK: The Company of Biologists.

Voipio J, Paalasmaa P, Taira T, Kaila K (1995) Pharmacological characterization of interstitial $\mathrm{pH}$ transients evoked by selective synaptic and exogenous activation of AMPA, NMDA, and $\mathrm{GABA}_{\mathrm{A}}$ receptors in the rat hippocampal slice. J Neurophysiol 74:633-642.

Voipio J, Lamsa K, Autere A-M, Smirnov S, Taira T, Kaila K (1996) Rise in extracellular $\mathrm{K}^{+}$and fall in $\mathrm{Ca}^{2+}$ induced by tetanic stimulation of inhibitory interneurons in area CA1 of rat hippocampal slices. Soc Neurosci Abstr 22:314.2.

Whittington MA, Traub RD, Jefferys JGR (1995) Synchronized oscillations in interneuron networks driven by metabotropic glutamate receptor activation. Nature 373:612-615.

Wong RKS, Watkins DJ (1982) Cellular factors influencing GABA response in hippocampal pyramidal cells. J Neurophysiol 48:938-951. 